\title{
MONETARY AND FISCAL POLICY INTERACTIONS IN AN EMERGING OPEN ECONOMY: A NON-RICARDIAN DSGE APPROACH
}

Aliya Algozhina
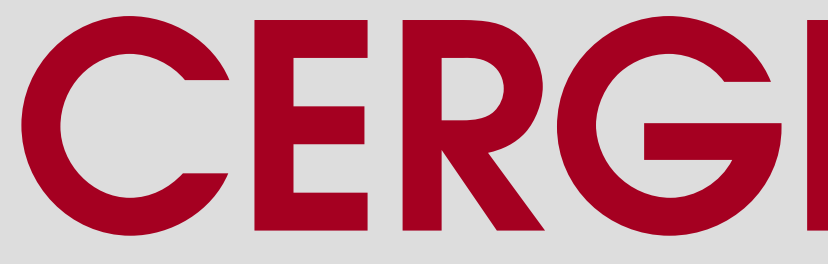

.




\section{Working Paper Series 476 (ISSN 1211-3298)}

\section{Monetary and Fiscal Policy Interactions in an Emerging Open Economy: a Non-Ricardian DSGE Approach}

Aliya Algozhina

CERGE-EI

Prague, December 2012 
ISBN 978-80-7343-280-5 (Univerzita Karlova. Centrum pro ekonomický výzkum a doktorské studium)

ISBN 978-80-7344-272-9 (Národohospodářský ústav AV ČR, v.v.i.) 


\title{
Monetary and Fiscal Policy Interactions in an Emerging Open Economy: a Non-Ricardian DSGE Approach
}

\author{
Aliya Algozhina* \\ CERGE-EI ${ }^{\dagger}$
}

\begin{abstract}
The monetary and fiscal policy interactions have gained a new research interest after the 2008 crisis due to the global increase of fiscal debt. This paper constructs a macroeconomic model of joint fiscal and monetary policy for an emerging open economy taking into account its structural uniqueness. In particular, the two instruments of monetary policy, interest rate and foreign exchange intervention, the two instruments of fiscal policy, public consumption and public investment, the two types of households, optimizers and rule-ofthumb individuals, and a foreign debt via collateral constraint are modeled here in a single DSGE framework. The parameters are calibrated for the case of Hungary using data over 1995Q1-2011Q3. The impulse response functions to public investment, public consumption, and interest rate shocks reveal some unconventional findings in favor of the fiscal theory of price level as opposed to the traditional monetarist doctrine.
\end{abstract}

\begin{abstract}
Abstrakt
Vzhledem ke globálnímu nárůstu fiskálních dluhů po roce 2008 zapř́íciněného ekonomickou krizí narůstá zájem o výzkum interakcí monetární a fiskální politiky. V tomto článku je navržen makroekonomický model s propojenou fiskální a monetární politikou v rozvíjející se otevřené ekonomice, který bere v potaz její strukturální jedinečnosti. V jednotném DSGE rámci jsou zde modelovány dva nástroje monetární politiky (úroková míra a devizové intervence), dva nástroje fiskální politiky (vládní spotřeba a vládní investice), dva typy domácností (jedinci optimalizující a jedinci následující jednoduchá pravidla) a zahraniční dluh modelovaný pomocí omezení na kolaterál. Parametry jsou kalibrovány na Mad'arských údajích za použití dat z období prvního kvartálu 1995 až třetího kvartálu 2011. Odezvy na impulzy $\mathrm{v}$ podobě vládních investic, spotřeby vlády a změny úrokové míry vedou $\mathrm{k}$ nekonvečním závěrům podporujícím fiskální teorii cenové úrovně v kontrastu k tradiční monetaristické doktríně.
\end{abstract}

Keywords: monetary policy, fiscal policy, emerging open economy, collateral constraint, fiscal theory of price level

JEL Classification: E31, E52, E62, E63, F41, H54, H63

*The author thanks Michal Kejak and Sergey Slobodyan for their helpful advice and insightful comments. All errors remaining in this text are the responsibility of the author (e-mail: aalgozhi@cerge-ei.cz). The financial support of the Czech Science Foundation project No. P402/12/G097 DYME Dynamic Models in Economics is acknowledged. The work is supported by the grant SVV-2012-265 801 as well.

${ }^{\dagger}$ CERGE-EI is a joint workplace of Charles University and the Economics Institute of the Academy of Sciences of the Czech Republic, Politickych veznu 7, 11121 Prague, Czech Republic. 


\section{Introduction}

For over two decades remarkable progress has been made in macroeconomic modeling by synthesizing the New Keynesian theory and the real business cycle theory. As a result, in recent years macroeconomic linkages have been intensively modeled using a dynamic stochastic general equilibrium (DSGE) approach, which primarily highlights the influential role of monetary policy (Christiano, Eichenbaum \& Evans, 2005; Smets \& Wouters, 2007). Central banks worldwide develop their core DSGE models to frame their policy decisions, discuss clearly the sources of fluctuations, and perform counterfactual policy experiments. Although there are still challenges (Tovar, 2008), the DSGE models inject an increased discipline to judgement, thinking, and communication about monetary policy. Apart from the advanced economies, those models are estimated for emerging markets as well (Castillo et al., 2006; Silveira, 2008; Andrle et al., 2009; Vilagi, 2008; Zeman \& Senaj, 2009; Iordanov \& Vassilev, 2008; Lee, 2009). However, fiscal policy in this framework is usually passive; thus, it can be either ignored or specified simply by a balanced government budget without any role for fiscal debt. In other words, Ricardian equivalence holds and monetary dominance is assumed, resulting in a weak fiscal side in the model.

Yet, the current post-crisis situation shows that active fiscal policy has been implemented globally, causing high fiscal debt across countries. In addition, the developed world has reached its zero lower bound of interest rates, when expansionary fiscal policy can be quite effective in terms of stimulating economic activity (Christiano, Eichenbaum \& Rebelo, 2011; Eggertsson, 2011; Woodford, 2011), and thus it may interact with the influential monetary policy which should be captured jointly in the model. Even earlier, Benigno and Woodford (2003) pointed out the problem of modeling these two policies in isolation, which appeared to be more inter-related than expected, from their analysis of optimal monetary and fiscal policy within a single framework.

The consequences of one policy decision to another occur because, on the one hand, the interest rate set by the monetary policy affects the burden of fiscal debt, which may appropriately adjust in response to the interest rate change, while on the other hand, fiscal stimulus changes output, which may in turn adjust a tradeoff between inflation and output facing the monetary policy. Moreover, according to the fiscal theory of price level (Leeper, 1991; Sims, 1994; Cochrane, 2011), persistent fiscal deficits without taxes or spending adjustments inevitably cause inflation, thus constraining monetary policy to achieve its goal of price stability. Both policies, therefore, should take into account the consequences of their decisions on the targets of the other policy in order to be consistent and endogenously effective in a 
macroeconomic outcome.

Currently, there are two streams of literature on monetary and fiscal policy interactions in a DSGE framework. The first one deals with the optimal policy rules assuming that either tax or government spending is the only fiscal instrument modeled jointly with the Taylor-type monetary policy rule (Schmitt-Grohe \& Uribe, 2007; Leith \& Wren-Lewis, 2007; Chadha \& Nolan, 2007). The second stream is focused on the fiscal multiplier defined as the ratio of a change in output to an exogenous change in the fiscal instrument (Woodford, 2011; Davig \& Leeper, 2011; Cogan, Cwik, Taylor \& Wieland, 2010; Christiano, Eichenbaum \& Rebelo, 2011; Eggertsson, 2011), apart from the various econometric estimations, which generally suffer from endogeneity, proper identification of fiscal shocks without any mix with automatic stabilizers, and ignorance of fiscal debt dynamics. Both of these streams of DSGE models, though, do not impose any heterogeneity of households, assuming instead a representative agent who optimizes his future consumption path by appropriate savings. This might result in a relatively low fiscal multiplier, because once there is fiscal expansion, active monetary policy tightens, and a high interest rate encourages households to save rather than to consume; thus, consumption declines.

Realizing this problem in assessing fiscal stimulus, researchers have suggested incorporating two types of households: savers or traditional Ricardian households who are also known as the standard optimizers having savings in assets, and spenders or non-Ricardian households who do not have access to financial markets and simply consume their disposable income each period (Mankiw, 2000). The latter type is sometimes referred to as the rule-of-thumb or liquidity constrained households in the literature. Gali, Lopez-Salido, and Valles (2007) have extended, therefore, the standard New Keynesian model by incorporating these two types of households which allowed them to demonstrate that government spending has an effect on consumption consistent with the evidence due to the interaction between the behavior of the rule-of-thumb consumers and sticky prices. A global integrated monetary and fiscal policy model constructed at the IMF (Kumhof et al., 2010) distinguishes these two types of households as well and estimates that multipliers of two-year stimulus range from 0.2 to 2.2 depending on the fiscal instrument, the extent of monetary accommodation, and the presence of a financial accelerator mechanism (Freedman et al., 2009).

However, the above models are applicable to the developed world and do not take into account three structural specifics relevant for an emerging open economy. First, an emerging economy conducts its monetary policy using at least two instruments: the interest rate in accordance with the standard Taylor rule and foreign 
exchange intervention to manage the nominal exchange rate (Blanchard, Dell'Ariccia \& Mauro, 2010). Second, fiscal policy can be active trying to stimulate the economy through an increase of public consumption and/or public investment ${ }^{1}$ and not much through cutting taxes, which are relatively inflexible to change and distortionary. Hence, fiscal debt may accumulate, breaking the traditional Ricardian equivalence assumption and highlighting the fiscal theory of price level as a new alternative view in contrast to monetarist doctrine. Third, emerging economies often have private sectors heavily indebted to the foreign world due to their underdeveloped domestic financial market to finance investments. Thus, they are vulnerable to an external shock of sudden stops, which is exactly the case they faced due to the global financial crisis of 2008. Moreover, sudden stops seem to be related to collateral constraint (Mendoza, 2010; Mendoza, 2006; Chari, Kehoe \& McGrattan, 2005; Kiyotaki \& Moore, 1997), affecting in turn the exchange rate, rather than to a financial accelerator mechanism à la Bernanke, Gertler, and Gilchrist (1999). This is because a sudden shrinkage of foreign funds supply can abruptly cause an economic downturn in developing economies, which used to constantly have capital inflows earlier.

In this respect, the aim of this paper is to build a DSGE model for an emerging open economy capturing these three structural specifics. The calibration of the model is based on Hungary as a first economy among all emerging markets severely hit by the global financial crisis that already felt in mid-October 2008. International organizations were called on for support using their emergency financing arrangements. In 2009, Hungary's real GDP fell by 6.7 percent, the euro-forint exchange rate depreciated by 12 percent, unemployment increased to 9.8 percent, positive net exports were 10 times higher than in 2008 due to the collapse in imports and capital outflows, and foreign exchange reserves of the central bank dropped significantly, especially in the second quarter of 2009. The main vulnerability of Hungary originated from its high public and private sector debt: fiscal debt amounted to 66 percent of its GDP, while external debt reached 97 percent of GDP at the end of 2007 (IMF, 2008).

Based on the constructed model, my focus is to understand how multiple instruments of monetary and fiscal policy interact to jointly affect inflation, exchange rate, and output in an economy borrowing from abroad to finance its investments. In particular, the impulse response functions to three exogenous shocks are examined:

\footnotetext{
${ }^{1}$ I treat public consumption and public investment as two separate fiscal policy instruments because each of them can have a different effect on output and potentially on inflation. According to Aschauer (1989), there is a positive relationship between public investment and the growth rate of labor productivity, while public consumption is negatively related to the growth of output per hour in the G-7 countries.
} 
public investment, public consumption, and interest rate.

In section two, I outline the model with two types of households, standard optimizers and rule-of-thumb households, firms acting in a monopolistically competitive market, two monetary policy rules for each instrument, and respective fiscal policy rules. Section three describes the calibrated values for parameters, the full list of which is provided in Appendix 6.1. Section four examines the impulse response functions, including the sensitivity to higher population fraction of rule-of-thumb households than in the baseline simulation. Section five concludes.

\section{Model}

Technically, the model has several frictions: an incomplete asset market, capital adjustment costs, collateral constraint, and a Calvo price setting. The crucial underlying assumption is that the foreign world is a saver, while the domestic economy is a borrower; thus, the foreign discount factor is higher than the domestic discount factor, as the domestic households might be relatively impatient compared to the foreign world. This assumption implies in turn that the interest rate of an emerging economy is always higher than the foreign interest rate, which is consistent with the evidence.

Since there are two types of households, only optimizers borrow from abroad and have a collateral constraint on physical capital. They also hold the domestic government bonds, own the firms, rent capital to the firms, and decide about investment. The firms monopolistically set prices on their intermediate goods à la Calvo (1983) and their profits are transferred to the optimizers. The labor market is assumed to be competitive, so that modeling unions or having high bargaining power over wages by households might be irrelevant in the emerging market setting.

The foreign world is modeled by its Phillips curve, AR (1) process for output, and the Taylor rule for interest rate. All foreign variables are denoted by an asterisk in this paper.

The domestic Taylor rule includes lagged interest rate, inflation, output, and the nominal exchange rate, but there is also a rule for the foreign exchange intervention responding to the nominal exchange rate and its change (Sarno \& Taylor, 2001). Public consumption and public investment respond to fiscal debt and output, capturing a procyclical fiscal policy. Public investment can be productive, accumulating public capital, which is an additional input in the Cobb-Douglass production function beyond labor and private capital. 


\subsection{Households}

The economy is populated by a continuum of households on the interval $[0,1]$, where the fraction $\mu$ is rule-of-thumb households. They do not have access to financial markets and consume all of their disposable income each period. In other words, they act myopically without any effect of a future policy on their economic decisions. The other $(1-\mu)$ fraction of households are forward-looking optimizers who hold government bonds, invest in private capital, rent capital to the firms, borrow from abroad, and receive profits from the monopolistic firms. The labor market is competitive, wages are the same across all households, and both types of households work the same number of hours. The superscript $S$ indicates a variable associated with savers (optimizers) and $N$ with non-savers (rule-of-thumb households).

The optimizing household maximizes its utility (Schmitt-Grohe \& Uribe, 2003):

$$
E_{0} \sum_{t=0}^{\infty} \beta^{t} \frac{\left[C_{t}^{S}-\phi^{-1} N_{t}^{\phi}\right]^{1-\sigma}-1}{1-\sigma}, \quad \phi>1, \sigma>1
$$

subject to the following budget constraint:

$$
C_{t}^{S}+I_{t}^{S}+b_{t}+R_{t-1}^{*} \frac{e_{t}}{e_{t-1}} \frac{b_{t-1}^{*}}{\pi_{t}}+T_{t}^{S}=W_{t} N_{t}+R_{t}^{k} K_{t-1}^{S}+R_{t-1} \frac{b_{t-1}}{\pi_{t}}+b_{t}^{*}+\Pi_{t}
$$

where $b_{t}=\frac{B_{t}}{P_{t}}$ is the real purchases of government bonds, $e_{t}$ is a nominal exchange rate (the units of domestic currency per unit of foreign currency), $b_{t}^{*}=e_{t} \frac{B_{t}^{*}}{P_{t}}$ is the real foreign borrowings denominated in domestic currency, $R_{t-1}$ and $R_{t-1}^{*}$ are the nominal gross domestic and foreign interest rates, $T_{t}^{S}$ is the real lump-sum taxes, $W_{t}$ is a real wage, $R_{t}^{k}$ is the real rental cost of private capital, $\pi_{t}=\frac{P_{t}}{P_{t-1}}$ is inflation, and $\Pi_{t}$ is the real profits transferred from the monopolistic firms.

Each $i \in\{S, N\}$ type of households has the CES consumption preferences over domestic and foreign goods with $\eta>0$ as an elasticity of substitution between goods:

$$
C_{t}(i)=\left[\gamma^{\frac{1}{\eta}} C_{H, t}^{\frac{\eta-1}{\eta}}(i)+(1-\gamma)^{\frac{1}{\eta}} C_{F, t}^{\frac{\eta-1}{\eta}}(i)\right]^{\frac{\eta}{\eta-1}},
$$

where $\gamma$ is a home-bias parameter, while $(1-\gamma)$ is a degree of openness. The typical consumption expenditures minimization by a household delivers the following CPI index:

$$
P_{t}=\left[\gamma P_{h, t}^{1-\eta}+(1-\gamma) P_{f, t}^{1-\eta}\right]^{\frac{1}{1-\eta}},
$$

which assumes the unit elasticity of substitution between domestic and foreign goods 
$\eta=1$ as in Gali (2008) for deriving the Phillips curve in Appendix 6.3. The aggregate consumption in turn is $C_{t}=\mu C_{t}^{N}+(1-\mu) C_{t}^{S}$.

The law of motion for private capital is specified according to Gali, Lopez-Salido, and Valles (2007):

$$
K_{t}^{S}=(1-\delta) K_{t-1}^{S}+\kappa\left(\frac{I_{t}^{S}}{K_{t-1}^{S}}\right) K_{t-1}^{S}, \quad \kappa^{\prime}>0, \kappa^{\prime \prime} \leq 0, \kappa^{\prime}(\delta)=1, \kappa(\delta)=\delta
$$

The collateral constraint relates gross foreign liabilities to a future value of capital (Faia \& Iliopulos, 2011) and always binds, assuming that foreign debt is permanently high in this economy ${ }^{2}$ :

$$
R_{t}^{*} b_{t}^{*}=E_{t}\left\{\Omega \frac{Q_{t+1} \pi_{t+1}}{e_{t+1} / e_{t}} K_{t}^{S}\right\}
$$

where $Q_{t}$ is a real shadow value of capital (Tobin's $\mathrm{Q}$ ) and $\Omega$ is an upper bound of leverage ratio.

The problem of the optimizer is, therefore, to maximize (1) with respect to $C_{t}^{S}, I_{t}^{S}, K_{t}^{S}, b_{t}, b_{t}^{*}, N_{t}$ subject to (2), (3), and (4). The first-order conditions of this problem are below, where $\lambda_{t}, \lambda_{t}^{k}$, and $\lambda_{t} \xi_{t}$ are the Lagrange multipliers of the constraints (2), (3), (4) respectively.

$$
\begin{gathered}
U_{C_{t}^{S}}=\lambda_{t}=\frac{1}{\left[C_{t}^{S}-\frac{N_{t}^{\phi}}{\phi}\right]^{\sigma}} \\
Q_{t}=\frac{1}{\kappa^{\prime}\left(\frac{I_{t}^{S}}{K_{t-1}^{S}}\right)}, \text { where } Q_{t}=\frac{\lambda_{t}^{k}}{\lambda_{t}} \\
Q_{t}=E_{t}\left\{\beta \frac{\lambda_{t+1}}{\lambda_{t}}\left[R_{t+1}^{k}+Q_{t+1}\left(1-\delta+\kappa\left(\frac{I_{t+1}^{S}}{K_{t}^{S}}\right)-\kappa^{\prime}\left(\frac{I_{t+1}^{S}}{K_{t}^{S}}\right) \frac{I_{t+1}^{S}}{K_{t}^{S}}\right)\right]+\xi_{t} \Omega \frac{Q_{t+1} \pi_{t+1}}{e_{t+1} / e_{t}}\right)_{(7)}^{(5)} \\
\frac{1}{R_{t}}=\beta E_{t}\left\{\frac{U_{C_{t+1}^{S}}}{U_{C_{t}^{S}}} \frac{P_{t}}{P_{t+1}}\right\} \\
\frac{1}{R_{t}^{*}}=\beta E_{t}\left\{\frac{U_{C_{t+1}^{S}}}{U_{C_{t}^{S}}} \frac{P_{t}}{P_{t+1}} \frac{e_{t+1}}{e_{t}}\right\}+\xi_{t} \\
W_{t}=N_{t}^{\phi-1}
\end{gathered}
$$

By dividing (9) into (8), we get the following uncovered interest rate parity (UIP)

\footnotetext{
${ }^{2}$ Occasionally binding collateral constraint is ruled out because it requires global solution methods, which may be infeasible to apply in such a complex model.
} 
condition:

$$
\frac{R_{t}}{R_{t}^{*}}=E_{t} \frac{e_{t+1}}{e_{t}}+\frac{\xi_{t}}{\beta} E_{t}\left\{\frac{U_{C_{t}^{S}}}{U_{C_{t+1}^{S}}} \pi_{t+1}\right\}+\operatorname{cov}_{t},
$$

where $\operatorname{cov}_{t}$ captures covariance terms.

The rule-of-thumb household has the same preferences as the optimizer. It chooses only consumption and labor and its budget constraint is simply this:

$$
C_{t}^{N}+T_{t}^{N}=W_{t} N_{t}
$$

The first-order conditions with respect to $N_{t}$ and $C_{t}^{N}$ are identical to the optimizer's solutions. Thus, the rule-of-thumb household faces the same labor supply condition (10).

\section{$2.2 \quad$ Firms}

Following Gali, Lopez-Salido, and Valles (2007), there are monopolistically competitive firms producing differentiated intermediate goods, and a perfectly competitive firm producing a final domestic good. The final domestic producer has a constant returns technology:

$$
Y_{t}=\left(\int_{0}^{1} X_{t}(j)^{\frac{\varepsilon-1}{\varepsilon}} d j\right)^{\frac{\varepsilon}{\varepsilon-1}}
$$

where $X_{t}(j)$ is the input amount of intermediate good $j$ and $\varepsilon>1$ is the elasticity of substitution between differentiated intermediate goods. It maximizes profit taking as given the domestic final goods price $P_{t}^{h}$ and intermediate goods prices $P_{t}^{h}(j)$ such that the optimal demand allocation is as follows:

$$
X_{t}(j)=\left(\frac{P_{t}^{h}(j)}{P_{t}^{h}}\right)^{-\varepsilon} Y_{t}
$$

Each intermediate goods firm maximizes its profits subject to three constraints. First, the identical Cobb-Douglass production function includes private capital, labor, and public capital.

$$
Y_{t}(j)=A_{t} K_{t-1}(j)^{\alpha} N_{t}(j)^{1-\alpha} K_{G, t-1}^{\psi}
$$

where the level of technology $A_{t}$ and the usage of public capital are common to all intermediate firms.

The second constraint is the demand schedule each firm $j$ faces (13). Third is that some firms cannot adjust their prices, according to price stickiness (Calvo, 1983). 
Each period, a fraction $(1-\theta)$ of firms adjusts their prices, while the respective fraction $\theta$ keeps their prices unchanged; thus, $\theta$ is an index of price stickiness.

Cost minimization, taking the real wage and rental cost of capital as given, implies the following real marginal cost common to all intermediate firms:

$$
M C_{t}=\frac{W_{t}^{1-\alpha}\left(R_{t}^{k}\right)^{\alpha}}{A_{t} K_{G, t-1}^{\psi}(1-\alpha)^{1-\alpha} \alpha^{\alpha}}
$$

The price setting decision involves picking $P_{t}^{h *}$ to maximize

$$
\sum_{k=0}^{\infty} \theta^{k} E_{t}\left\{D_{t, t+k} Y_{t+k}(j)\left(\frac{P_{t}^{h *}}{P_{t+k}^{h}}-M C_{t+k}\right)\right\},
$$

where $D_{t, t+k}=\beta^{k} E_{t}\left(\frac{U_{C_{t+1}^{S}}}{U_{C_{t}^{S}}}\right)$ is a stochastic discount factor coming from the optimizing household's problem, subject to the demand constraint according to (13):

$$
Y_{t+k}(j)=\left(\frac{P_{t}^{h *}}{P_{t+k}^{h}}\right)^{-\varepsilon} Y_{t+k}
$$

The first-order condition of this price setting decision is as follows:

$$
\sum_{k=0}^{\infty} \theta^{k} E_{t}\left\{D_{t, t+k} Y_{t+k}(j)\left(\frac{P_{t}^{h *}}{P_{t+k}^{h}}-\mu^{p} M C_{t+k}\right)\right\}=0
$$

where $\mu^{p}=\frac{\varepsilon}{\varepsilon-1}$ is a frictionless price markup.

The Phillips curve for a small open economy is derived according to Cali (2008) in Appendix 6.3. It differs from the standard closed-economy version due to distinction between domestic price inflation and aggregate CPI inflation; thus, the economy's average real marginal cost includes the real exchange rate in addition.

\section{$2.3 \quad$ Fiscal policy}

The government collects lump-sum taxes and issues one-period bonds to finance its interest payments and expenditures, which are assumed to go exclusively to home goods. The expenditures include public consumption $G_{t}^{C}$ and public investment $G_{t}^{I}$. The government budget constraint can be written as follows:

$$
b_{t}+T_{t}=G_{t}^{I}+G_{t}^{C}+R_{t-1} b_{t-1},
$$

where $T_{t}=(1-\mu) T_{t}^{S}+\mu T_{t}^{N}$. 
Public investment is productive, so that the law of motion for public capital is given by this:

$$
K_{G, t}=\left(1-\delta^{g}\right) K_{G, t-1}+G_{t}^{I}
$$

The two fiscal instruments, public investment and public consumption, have the following rules responding to fiscal debt and output in order to capture business cycles (Traum \& Yang, 2011):

$$
\begin{aligned}
\widehat{G_{t}^{I}} & =\rho_{G I} \widehat{G_{t-1}^{I}}+\left(1-\rho_{G I}\right)\left(\vartheta_{G I} \widehat{Y}_{t}-\gamma_{G I} \widehat{b}_{t-1}\right)+\epsilon_{t}^{G I} \\
\widehat{G_{t}^{C}} & =\rho_{G C} \widehat{G_{t-1}^{C}}+\left(1-\rho_{G C}\right)\left(\vartheta_{G C} \widehat{Y}_{t}-\gamma_{G C} \widehat{b}_{t-1}\right)+\epsilon_{t}^{G C}
\end{aligned}
$$

Hats, hereafter, denote the deviations of variables from their steady states.

Since fiscal debt clears the government budget constraint, the lump-sum taxes require a separate equation, which includes fiscal debt and public spending similar to Gali, Lopez-Salido, and Valles (2007):

$$
\widehat{T}_{t}=\varphi_{b} \widehat{b}_{t-1}+\varphi_{I} \widehat{G_{t}^{I}}+\varphi_{C} \widehat{G_{t}^{C}}
$$

Note, there is no shock to lump-sum taxes in (21) assuming that fiscal debt is not generated by the tax cuts in the first place; only public investment and public consumption can suddenly increase.

\subsection{Monetary policy}

The nominal interest rate responds to its lagged value, CPI inflation, output, and the nominal exchange rate according to the Taylor rule below:

$$
\widehat{R}_{t}=\rho \widehat{R}_{t-1}+(1-\rho)\left[\phi_{\pi} \pi_{t}+\phi_{y} \widehat{Y}_{t}+\phi_{e} \widehat{e}_{t}\right]+\epsilon_{t}
$$

Foreign exchange intervention as a purchase of foreign currency by the central bank has its separate rule responding to the nominal exchange rate and its rate of depreciation $^{3}$ (Sarno \& Taylor, 2001):

$$
\widehat{\operatorname{Int}}_{t}=\alpha_{1} \widehat{e}_{t}+\alpha_{2} \Delta \widehat{e}_{t}+\epsilon_{t}^{i n t}, \text { where } \alpha_{1}<0, \alpha_{2}<0
$$

Reserves or net foreign assets of the central bank can be affected by its foreign exchange intervention:

$$
N F A_{t}=N F A_{t-1}+\operatorname{Int}_{t}
$$

\footnotetext{
${ }^{3}$ Since the exchange rate is defined as a price of foreign currency in terms of domestic currency, the higher $\Delta \widehat{e}_{t}$ is, the more domestic currency depreciates.
} 


\subsection{Market clearing conditions}

Labor, capital, and goods markets clear according to the following conditions:

$$
\begin{gathered}
N_{t}=\int_{0}^{1} N_{t}(j) d j, \quad K_{t}=\int_{0}^{1} K_{t}(j) d j=(1-\mu) K_{t}^{S} \\
Y_{t}=C_{t}+(1-\mu) I_{t}^{S}+G_{t}^{C}+G_{t}^{I}+N X_{t}
\end{gathered}
$$

The balance of payments of the domestic economy requires that the sum of current account and financial account should be equal to the change of central bank reserves which is, according to equation (24), the foreign exchange intervention:

$$
N X_{t}=(1-\mu)\left(R_{t-1}^{*} \frac{e_{t}}{e_{t-1}} \frac{b_{t-1}^{*}}{\pi_{t}}-b_{t}^{*}\right)+\operatorname{Int}_{t}
$$

\subsection{The foreign world}

The foreign world is specified by the following three equations:

$$
\begin{gathered}
\widehat{Y}_{t}^{*}=\rho_{Y^{*}} \widehat{Y}_{t-1}^{*}+\epsilon_{t}^{Y^{*}} \\
\widehat{R}_{t}^{*}=\phi_{\pi}^{*} \pi_{t}^{*}+\phi_{y}^{*} \widehat{Y}_{t}^{*}+\epsilon_{t}^{i^{*}} \\
\pi_{t}^{*}=\beta^{*} E_{t} \pi_{t+1}^{*}+\lambda^{*}\left(\sigma+\frac{\phi^{*}+\alpha^{*}}{1-\alpha^{*}}\right) \widehat{Y}_{t}^{*}
\end{gathered}
$$

The Phillips curve (29) is in accordance with the standard New Keynesian model (Gali, 2008), assuming that the foreign world is a relatively large economy.

The model includes 16 endogenous variables constituting a system of 16 equations, where the variables are represented in log-deviations from their steady states: inflation $\pi_{t}$, the aggregate consumption of households $\widehat{C}_{t}$, hours worked $\widehat{N}_{t}$, domestic interest rate $\widehat{R}_{t}$, net exports $\widehat{N X}_{t}$, foreign exchange intervention $\widehat{I n t}_{t}$, foreign interest rate $\widehat{R}_{t}^{*}$, foreign inflation $\pi_{t}^{*}$, foreign output $\widehat{Y}_{t}^{*}$, foreign debt $\widehat{b}_{t}^{*}$, private capital $\widehat{K}_{t}$, public capital $\widehat{K}_{G, t}$, nominal exchange rate $\widehat{e}_{t}$, fiscal debt $\widehat{b}_{t}$, public consumption $\widehat{G_{t}^{C}}$, and output $\widehat{Y}_{t}$. The system of log-linear equations consists of the Taylor rule (22), foreign exchange intervention policy (23), public consumption equation (20), three foreign world expressions (27, 28, and 29), and the other 10 equations represented in Appendix 6.4. 


\section{Calibration}

All values for the parameters can be divided into three sets: standard values borrowed from other studies because of the non-availability of respective Hungarian data, fixed values borrowed from the estimated Hungarian DSGE model (Vilagi, 2008), and specifically calibrated parameters for this model. The full list of calibrated parameters is provided in Appendix 6.1. The first set includes depreciation rates for private and public capital $\delta=0.025, \delta^{g}=0.02$ (Traum \& Yang, 2011), frictionless price markup $\mu^{p}=0.2$, the elasticity of investment with respect to Tobin's Q $z=1$ (Gali, Lopez-Salido \& Valles, 2007), the inverse of intertemporal elasticity of substitution for consumption $\sigma=2$ (Schmitt-Grohe \& Uribe, 2003), the elasticity of wages with respect to hours worked $\phi=2$, output response in the Taylor rule $\phi_{y}=0.125$, and the exchange rate change response in the intervention rule $\alpha_{2}=-0.62$ (Gartner, 1987). The foreign parameters are set at their standard values: $\beta^{*}=0.99, \phi^{*}=2$, inflation and output responses in the Taylor rule $\phi_{\pi}^{*}=1.5, \phi_{y}^{*}=0.125$ (Gali, 2008), price stickiness $\theta^{*}=0.75$ (Gali, Lopez-Salido \& Valles, 2007), output elasticity to capital $\alpha^{*}=0.32$, and persistence in the foreign output $\rho_{Y^{*}}=0.8$.

The second set consists of posterior estimates of Vilagi (2008) and his fixed parameters: the persistence of interest rate $\rho=0.76$, inflation and exchange rate responses in the Taylor rule $\phi_{\pi}=1.37, \phi_{e}=0.025$, price stickiness $\theta=0.9$, the fraction of rule-of-thumb households $\mu=0.25$, and an autoregressive coefficient in productivity $\rho_{a}=0.8$.

The third largest set consists of calibrated parameters using the averages of Hungarian data ${ }^{4}$ over 1995Q1-2011Q3 for the steady state of variables derived in Appendix 6.2. In particular, the ratios of consumption, public consumption, public investment, net exports, and external debt to GDP are $c_{y}=0.66, g_{y}^{C}=0.1, g_{y}^{I}=$ $0.035, n x_{y}=0.0001$, and $b_{y}^{*}=1.16$ respectively. The degree of openness is calculated as a ratio of imports to GDP, $1-\gamma=0.69$; thus, domestic bias $\gamma$ is equal to 0.31 . The discount factor is set to 0.97 because the average T-bill rate is used as a proxy for the policy interest rate, which is 3 percent per quarter. The domestic interest rate matters exclusively for the government bonds in this model, as investment is financed by the foreign debt rather than the domestic financial market. The upper bound of leverage ratio $\Omega$ appears to be 0.14 using the steady state expression of collateral

\footnotetext{
${ }^{4}$ The data include real GDP, CPI-deflated consumption, public consumption, fixed capital formation, exports, imports, T-bill rate, CPI, fiscal debt, and fiscal revenues all from the IFS database of IMF, the euro-forint exchange rate and external debt in euro from the webpage of the Central Bank of Hungary.
} 
constraint (34). The elasticity of output with respect to capital $\alpha$ is equal to 0.45 , higher than its standard level because of the specific steady state rental cost of capital (31). The elasticity of output with respect to public capital $\psi$ corresponds to 0.08 based on equation (32). The exchange rate response of foreign exchange intervention $\alpha_{1}$ is -0.12 using the steady state equation for intervention (33). Fiscal parameters are calibrated based on the steady state expressions for public consumption, public investment, and lump-sum taxes in Appendix 6.2: $\vartheta_{G I}=1.03, \gamma_{G I}=0.38, \gamma_{G C}=$ 0.4 , and $\varphi_{I}=0.3$.

Some parameters are obtained by running regressions according to the model's equations and using the seasonally adjusted log of real data. For example, the autoregressive coefficient in the public consumption equation (20) is equal to 0.4, while the output response of public consumption appears to be positive $\vartheta_{G C}=1.18$ suggesting a procyclical fiscal policy. The lump-sum taxes' response to fiscal debt $\varphi_{b}=0.4$ and to public consumption $\varphi_{C}=0.3$ are obtained by running the regression of fiscal revenues on fiscal debt and public consumption.

\section{Simulation}

The exogenous shocks of 1 percent to public investment, public consumption, and interest rate are used to examine the impulse response functions in this section. Two main findings are worth-highlighting. First, public investment and public consumption are the two distinct fiscal instruments which differently affect inflation, exchange rate, and output. Even if there is a high fraction of rule-of-thumb households, public consumption does not boost private consumption and output; instead, the fiscal multiplier of public investment changes significantly. Second, foreign debt seems to determine the exchange rate, which is important for inflation dynamics due to its pass-through effect rather than policy interest rate. 
Figure 1. Impulse responses to a public investment shock
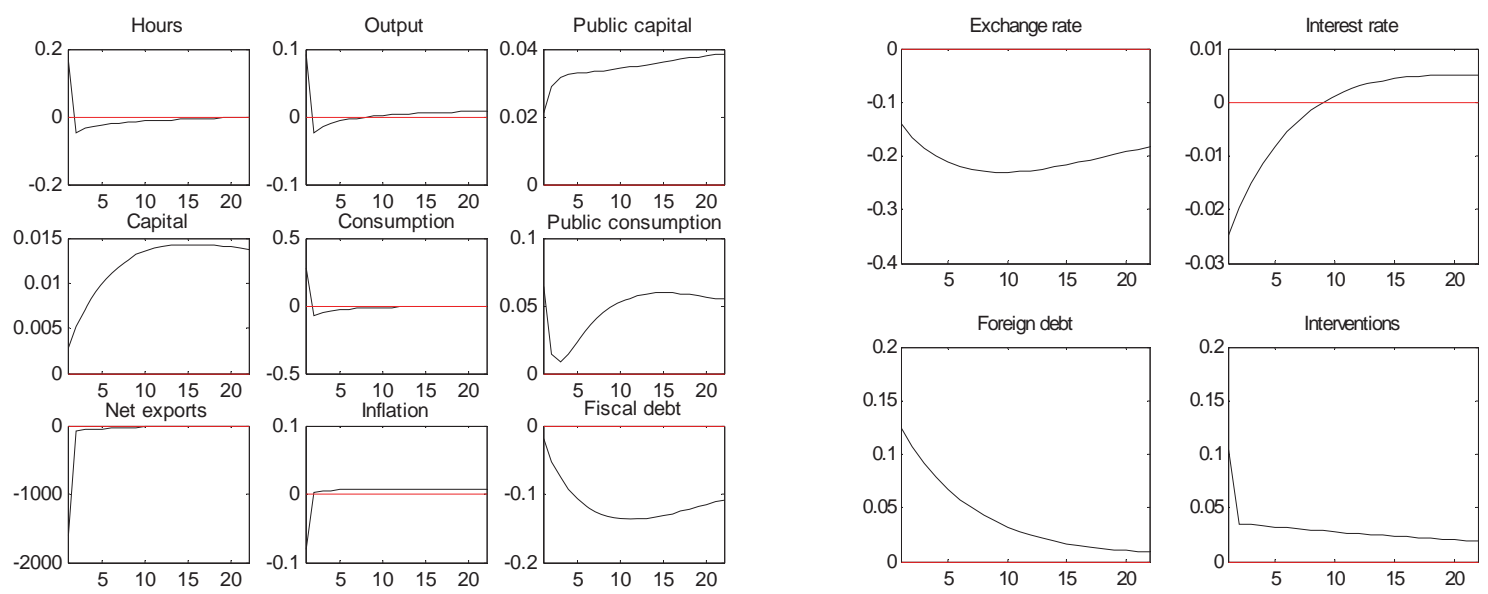

Figure 2. Impulse responses to a public consumption shock
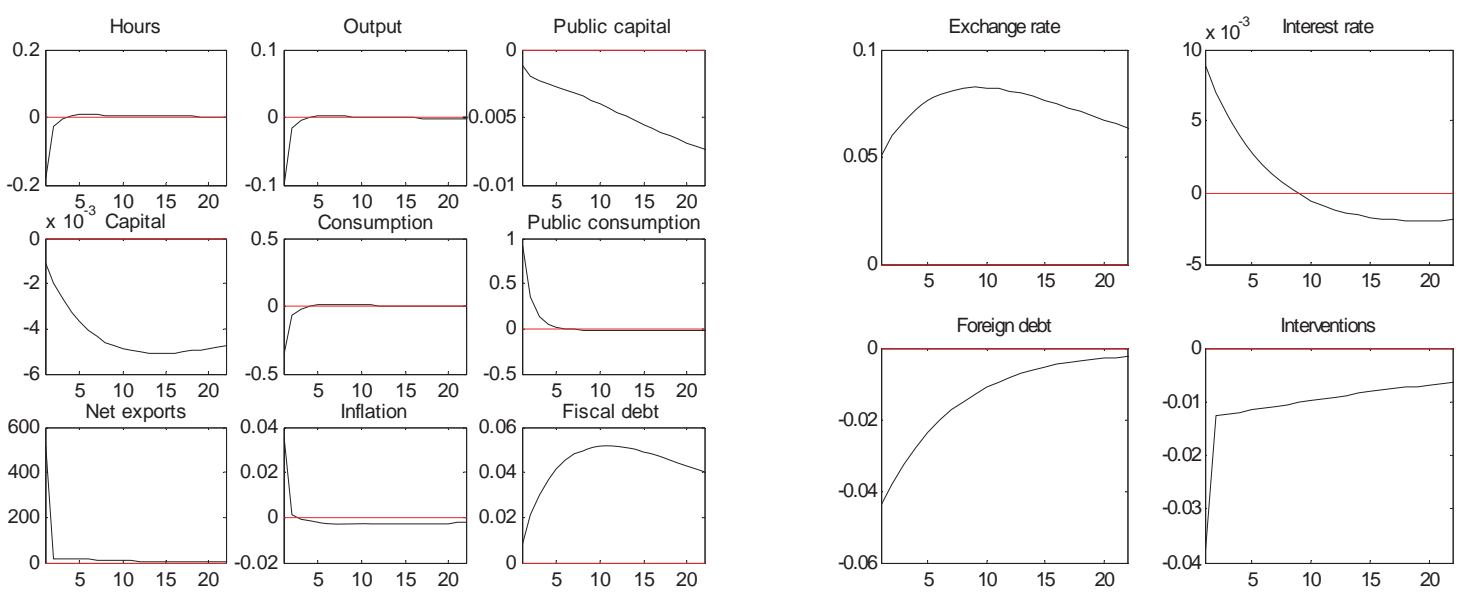

In Figure 1, the public investment shock accumulates public capital making the economy more productive, thus decreasing inflation. Low inflation implies a decline in interest rate, which stimulates consumption and hence hours worked, since there is a positive correlation between consumption and hours in the model. As labor has higher output elasticity than private capital, the increased hours worked and the accumulated public capital raise output in turn. Public consumption rises as well due to procyclical fiscal policy (positive output responses in the fiscal rules $\vartheta_{G C}$ and $\left.\vartheta_{G I}\right)$. The decline in interest rate, meanwhile, encourages households to substitute government bonds with investment in physical capital; thus, foreign debt increases, meaning that capital flows in, exerting appreciation pressure on the exchange rate. The exchange rate appreciation triggers foreign exchange intervention in terms of 
buying foreign reserves and selling the domestic currency by a central bank and, together with the rise in consumption, decreases net exports. In contrast, the public consumption shock in Figure 2 produces the opposite effects through the same linkages, but originates from increased inflation. In other words, public consumption seems to cause inflation, supporting the fiscal theory of price level, while public investment is not inflationary. Therefore, monetary policy is tight in response to a public consumption shock, while it accommodates expansionary fiscal policy if public investment is made.

As a sensitivity analysis, the model has been simulated under a higher fraction of rule-of-thumb households than the baseline version assumes, $\mu=0.75$ versus $\mu=0.25$, to compare the impulse response functions to fiscal shocks. The figures in Appendix 6.5 show that the public investment shock does not significantly boost consumption, hours worked, and output as before, because the decline in interest rate does not matter for the consumption of rule-of-thumb households who do not have access to savings. The net exports fall less in turn, as consumption increases less. Interestingly, the public consumption shock still reduces the private consumption and output despite the high fraction of rule-of-thumb households, which might be against the conventional view on fiscal multiplier, but given the increased inflation this outcome seems plausible in this non-Ricardian setting.

Figure 3. Impulse responses to an interest rate shock
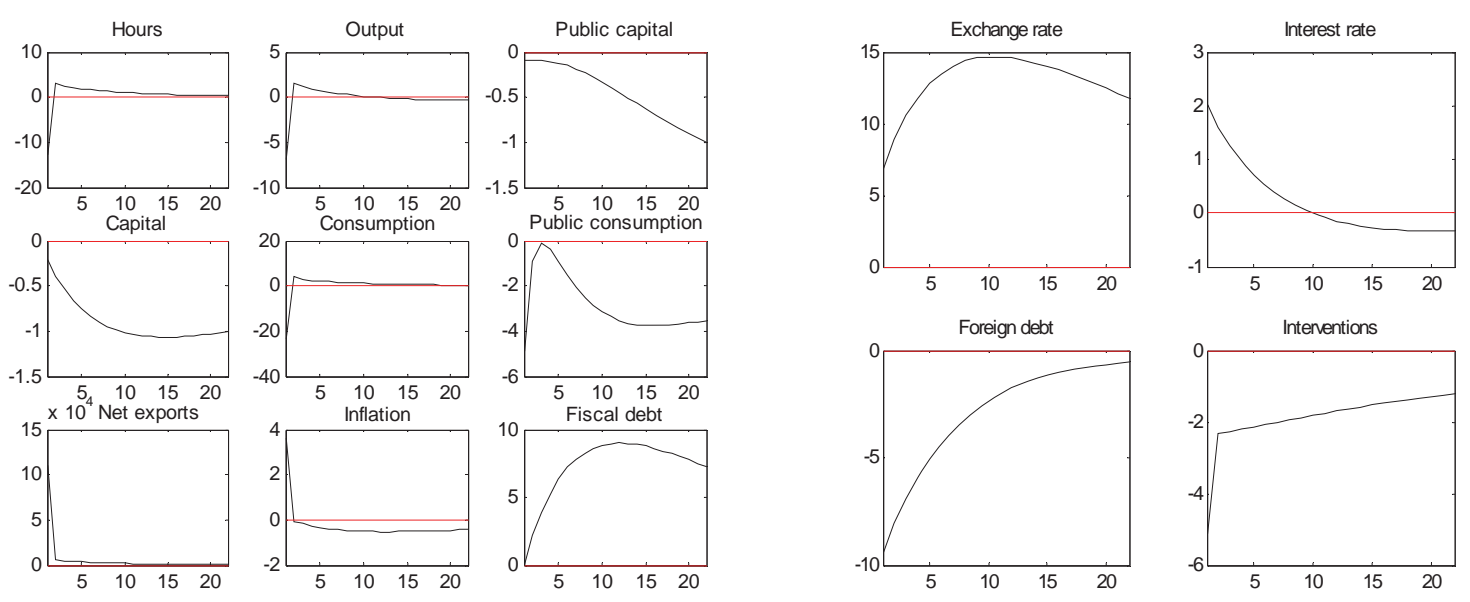

The positive interest rate shock in Figure 3 reduces the foreign debt as households prefer to invest in government bonds as opposed to physical capital; thus, they pay back their foreign debt and refrain from borrowing, which implies that capital flows out, depreciating the exchange rate. This outcome of exchange rate depreciation caused by the increased interest rate is not in line with the conven- 
tional Mundell-Fleming model and UIP prediction. According to those traditional concepts, an increase in domestic interest rate relative to the foreign interest rate should appreciate the exchange rate, because capital flows into the country. However, this model explains via its collateral constraint that foreign debt financing the domestic investments may matter for the exchange rate determination per se. The sudden stops crisis in emerging open economies, indeed, brought the exchange rate depreciation due to a shortage of foreign funds supply, loss in foreign reserves by a central bank, net exports surge due to capital reversals argument (Mendoza, 2010), and collapses in consumption, hours worked, and output.

Moreover, inflation has increased in response to the interest rate shock because of the complete pass-through effect from the depreciated exchange rate. This finding that high interest rate may cause inflation is counterintuitive to the conventional monetarist view, yet seems to be consistent with the fiscal theory of price level and associated argument by Leeper (2013) and Cochrane (2011) that in an economy with high fiscal debt, an increase of interest rate can stimulate demand, thus inflation as well.

\section{Conclusion}

This paper develops a DSGE model designed for an emerging open economy to understand monetary and fiscal policy interactions in affecting inflation, exchange rate, and output. The model captures a set of structural specifics: two monetary instruments - interest rate and foreign exchange intervention, two fiscal instruments public consumption and public investment, and the foreign debt of private sector to finance investments via collateral constraint. The constructed framework combines the New Keynesian model of a small open economy with the two types of households, optimizing individuals and rule-of-thumb households, and integrates three equations for the foreign world, relaxing the assumption of Ricardian equivalence.

The novelty of this paper is threefold, as it reveals unconventional findings of an emerging open economy, supporting the fiscal theory of price level within a debtbased DSGE framework. First, public consumption is inflationary and has a negative fiscal multiplier as opposed to public investment, which boosts output and does not bring inflation. Second, the exchange rate is determined by the level of foreign debt to finance investments, rather than by the interest rate difference. Third, the pass-through effect from the exchange rate to inflation is significant, while its raised policy interest rate may contribute to inflation. Overall, emerging open economies may prefer to have public investment rather than public consumption, stay aware 
of the foreign debt effect on the exchange rate, and be cautious with policy interest rate, as its increase can cause inflation, contrary to the traditional monetarist theory.

\section{References}

[1] Andrle, M., Hledik, T., Kamenik, O., \& Vlcek, J. (2009). Implementing the new structural model of the Czech National Bank. Czech National Bank Working paper 2, 1-49.

[2] Aschauer, D. A. (1989). Is public expenditure productive? Journal of Monetary Economics, 23, 177-200.

[3] Baxter, M., \& King, R. G. (1993). Fiscal policy in general equilibrium. American Economic Review, 83(3), 315-334.

[4] Benigno, P., \& Woodford, M. (2003). Optimal monetary and fiscal policy: a linear quadratic approach. NBER Working Paper 9905, 1-68.

[5] Bernanke, B., Gertler, M., \& Gilchrist, S. (1999). The financial accelerator in a quantitative business cycle framework. In Handbook of Macroeconomics. Amsterdam: North Holland.

[6] Blanchard, O., Dell'Ariccia, G., \& Mauro, P. (2010). Rethinking macroeconomic policy. IMF Staff Position Note SPN/10/03, 1-18.

[7] Buera, F. J., \& Moll, B. (2012). Aggregate implications of a credit crunch. NBER Working Paper 177r5, 1-47.

[8] Calvo, G. (1983). Staggered prices in a utility maximizing framework. Journal of Monetary Economics, 12(3), 383-398.

[9] Castillo, P., Montoro, C., \& Tuesta, V. (2006). An estimated stochastic general equilibrium model with partial dollarization: a Bayesian approach. Central Bank of Chile Working Paper 381, 2-68.

[10] Cespedes, L. F., Chang, R., \& Velasco, A. (2004). Balance sheet and exchange rate policy. American Economic Review, 94(4), 1183-1193.

[11] Chadha, J. S., \& Nolan, C. (2007). Optimal simple rules for the conduct of monetary and fiscal policy. Journal of Macroeconomics, 29, 665-689.

[12] Chari, V. V., Kehoe, P. J., \& McGrattan, E. R. (2005). Sudden stops and output drops. American Economic Review, 95(2), 381-387.

[13] Christiano, L., Eichenbaum, M., \& Evans, C. (2005). Nominal rigidities and the dynamic effects of a shock to monetary policy. Journal of Political Economy, $113(1), 1-46$. 
[14] Christiano, L., Eichenbaum, M., \& Rebelo, S. (2011). When is the government spending multiplier large? Journal of Political Economy, 119(1), 78-121.

[15] Cochrane, J. H. (2011). Understanding policy in the great recession: some unpleasant fiscal arithmetic. European Economic Review, 55(1), 2-30.

[16] Cogan, J. F., Cwik, T., Taylor, J. B., \& Wieland, V. (2010). New Keynesian versus old Keynesian government spending multipliers. Journal of Economic Dynamics and Control, $34(3), 281-295$.

[17] Davig, T., \& Leeper, E. M. (2011). Monetary-fiscal policy interactions and fiscal stimulus. European Economic Review, 55(2), 211-227.

[18] De Paoli, B. (2009). Monetary policy and welfare in a small open economy. Journal of International Economics, 7r7(1), 11-22.

[19] Eggertsson, G. B. (2011). What fiscal policy is effective at zero interest rates? In NBER Macroconomics Annual 2010, Volume 25, 59-112. National Bureau of Economic Research, Inc.

[20] Faia, E., \& Iliopulos, E. (2011). Financial openness, financial frictions and optimal monetary policy. Journal of Economic Dynamics and Control, 35(11), 1976-1996.

[21] Freedman, C., Kumhof, M., Laxton, D., Muir, D., \& Mursula, S. (2009). Fiscal stimulus to the rescue? Short-run benefits and potential long-run costs of fiscal deficits. IMF Working Paper WP/09/255, 2-40.

[22] Fukac, M., \& Pagan, A. (2010). Limited information estimation and evaluation of DSGE models. Journal of Applied Econometrics, 25(1), 55-70.

[23] Fukac, M., \& Pagan, A. (2010a). Structural macro-econometric modelling in a policy environment. Federal Reserve Bank of Kansas Working Paper RWP 10-08, 1-37.

[24] Gali, J. (2008). Monetary policy, inflation, and the business cycle: an introduction to the New Keynesian framework. USA: Princeton University Press, 1-203.

[25] Gali, J., Lopez-Salido, J. D., \& Valles, J. (2007). Understanding the effects of government spending on consumption. Journal of the European Economic Association, 5(1), 227-270.

[26] Garcia-Cicco, J., Pancrazi, R., \& Uribe, M. (2010). Real business cycles in emerging countries? American Economic Review, 100 (5), 2510-31.

[27] Gartner, M. (1987). Intervention policy under floating exchange rates: an analysis of the Swiss case. Economica, 54 (216), 439-453.

[28] IMF (2008). Hungary: request for stand-by arrangement. IMF Country Report, $08 / 361,1-54$. 
[29] Iordanov, I., \& Vassilev, A. (2008). A small open economy model with a currency board feature: the case of Bulgaria. National Bank of Bulgaria Discussion Paper DP/63/2008, 3-46.

[30] Kiyotaki, N., \& Moore, J. (1997). Credit cycles. Journal of Political Economy, $105(2), 211-248$.

[31] Kumhof, M., Laxton, D., Muir, D., \& Mursula, S. (2010). The global integrated monetary and fiscal model (GIMF) - theoretical structure. IMF Working Paper $W P / 10 / 34,2-73$.

[32] Lee, J. (2009). Are structural parameters of DSGE models stable in Korea? Bank of Korea Working Paper 381, 1-36.

[33] Leeper, E. M. (1991). Equilibria under "active" and "passive" monetary and fiscal policies. Journal of Monetary Economics, 27(1), 129-147.

[34] Leeper, E. M. (2013). Fiscal limits and monetary policy. NBER Working Paper 1887r, 1-22.

[35] Leith, C., \& Wren-Lewis, S. (2007). Fiscal sustainability in a New Keynesian model. University of Oxford Discussion Paper 310, 1-37.

[36] Mankiw, N. G. (2000). The savers-spenders theory of fiscal policy. American Economic Review, 90(2), 120-125.

[37] Mendoza, E. G. (2010). Sudden Stops, financial crises, and leverage. American Economic Review, 100(5), 1941-1966.

[38] Mendoza, E. G. (2006). Lessons from the debt-deflation theory of sudden stops. American Economic Review, 96(2), 411-416.

[39] Sarno, L., \& Taylor, M. P. (2001). Official intervention in the foreign exchange market: is it effective and, if so, how does it work? Journal of Economic Literature, 39(3), 839-868.

[40] Schmitt-Grohe, S., \& Uribe, M. (2003). Closing small open economy models. Journal of International Economics, 61(1), 163-185.

[41] Schmitt-Grohe, S., \& Uribe, M. (2007). Optimal simple and implementable monetary and fiscal rules. Journal of Monetary Economics, 54 (6), 1702-1725.

[42] Silveira, M. A. (2008). Using a Bayesian approach to estimate and compare New Keynesian DSGE models for the Brazilian economy: the role for endogenous persistence. Revista Brasileira de Economia, 62(3), 333-357.

[43] Sims, C. A. (1994). A simple model for study of the determination of the price level and the interaction of monetary and fiscal policies. Economic Theory, 4, 381-399.

[44] Smets, F., \& Wouters, R. (2007). Shocks and frictions in US business cycles: a Bayesian DSGE approach. American Economic Review, 97(3), 586-606. 
[45] Tovar, C. E. (2008). DSGE models and central banks. BIS Working paper 258, $1-23$.

[46] Traum, N., \& Yang, S. (2011). When does government debt crowd out investment? 2011 Meeting Papers 479, Society for Economic Dynamics, 1-42.

[47] Vilagi, Z. (2008). An estimated DSGE model of the Hungarian economy. Magyar Nemzeti Bank Working Paper 2008/9, 3-81.

[48] Walsh, C. E. (2010). Monetary theory and policy. USA: The MIT Press, 1-613.

[49] Woodford, M. (2003). Interest and prices: foundations of a theory of monetary policy. USA: Princeton University Press.

[50] Woodford, M. (2011). Simple analytics of the government expenditure multiplier. American Economic Journal: Macroeconomics, 3(1), 1-35.

[51] Zeman, J., \& Senaj, M. (2009). DSGE model - Slovakia. National Bank of Slovakia Working Paper 3/2009, 4-37. 


\section{Appendix}

\subsection{Table of parameters}

\begin{tabular}{|c|c|}
\hline Parameter & Definition \\
\hline$\beta=0.97$ & discount factor \\
\hline$\gamma=0.31$ & home-bias in consumption \\
\hline$\Omega=0.14$ & the upper bound of leverage ratio \\
\hline$\alpha=0.45$ & output elasticity to private capital \\
\hline$\psi=0.08$ & output elasticity to public capital \\
\hline$\delta=0.025$ & the depreciation rate of private capital \\
\hline$\delta^{g}=0.02$ & the depreciation rate of public capital \\
\hline$\phi=\phi^{*}=2$ & wage elasticity to hours worked, domestic and foreign \\
\hline$\sigma=2$ & the inverse of intertemporal elasticity of substitution for $C_{t}$ \\
\hline$\theta=0.9$ & the index of price stickiness \\
\hline$\mu^{p}=0.2$ & frictionless price markup \\
\hline$\mu=0.25$ & the fraction of rule-of-thumb households \\
\hline$\phi_{\pi}=1.37$ & inflation response in the Taylor rule \\
\hline$\phi_{y}=\phi_{y}^{*}=0.125$ & output response in the Taylor rule, domestic and foreign \\
\hline$\phi_{e}=0.025$ & nominal exchange rate response in the Taylor rule \\
\hline$\alpha_{1}=-0.12$ & exchange rate response in the intervention rule \\
\hline$\alpha_{2}=-0.62$ & exchange rate change response in the intervention rule \\
\hline$\gamma_{G C}=0.4$ & the response of public consumption to fiscal debt \\
\hline$\gamma_{G I}=0.38$ & the response of public investment to fiscal debt \\
\hline$\vartheta_{G I}=1.03$ & the response of public investment to output \\
\hline$\vartheta_{G C}=1.18$ & the response of public consumption to output \\
\hline$\varphi_{b}=0.4$ & the response of lump-sum taxes to fiscal debt \\
\hline$\varphi_{C}=0.3$ & the response of lump-sum taxes to public consumption \\
\hline$\varphi_{I}=0.3$ & the response of lump-sum taxes to public investment \\
\hline $\begin{array}{l}\rho_{G C}=\rho_{G I}=0.4 \\
\rho=0.76\end{array}$ & $\begin{array}{l}\text { persistence in public consumption and public investment } \\
\text { interest rate persistence in the Taylor rule }\end{array}$ \\
\hline $\begin{array}{l}\rho_{a}=\rho_{Y^{*}}=0.8 \\
z=1\end{array}$ & $\begin{array}{l}\text { persistence in productivity and foreign output } \\
\text { investment elasticity to Tobin's Q }\end{array}$ \\
\hline$c_{y}=0.66$ & private consumption-to-GDP ratio \\
\hline$g_{y}^{C}=0.1$ & public consumption-to-GDP ratio \\
\hline$g_{y}^{I}=0.035$ & public investment-to-GDP ratio \\
\hline$n x_{y}=0.0001$ & net exports-to-GDP ratio \\
\hline$b_{y}^{*}=1.16$ & external debt-to-GDP ratio \\
\hline$\beta^{*}=0.99$ & foreign discount factor \\
\hline$\phi_{\pi}^{*}=1.5$ & foreign inflation response in the Taylor rule \\
\hline$\theta^{*}=0.75$ & foreign price stickiness \\
\hline$\alpha^{*}=0.32$ & foreign output elasticity to capital \\
\hline
\end{tabular}

\subsection{Steady state}

The steady state values for the endogenous variables denoted by bars are shown in terms of the model's parameters in this appendix. The first-order condition with 
respect to government bonds $b_{t}(8)$ gives that $\bar{R}=\frac{1}{\beta}$, while with respect to foreign debt $b_{t}^{*}(9)$ suggests $\bar{\xi}=\beta^{*}-\beta$ at steady state. Similarly, $\bar{R}^{*}=\frac{1}{\beta^{*}}$.

The public investment equation (19) can be represented as $\overline{G_{I}}=\frac{{\overline{G_{I}}}_{\rho_{G I}} \bar{Y}^{\left(1-\rho_{G I} \vartheta_{G I}\right.}}{\bar{b}^{\left(1-\rho_{G I} \gamma_{G I}\right.}}$, which allows expressing $\overline{G_{I}}=\frac{\bar{Y}^{\vartheta} G I}{\bar{b}^{\gamma} G I}$. Similarly, the steady state public consumption is as follows based on the equation (20) $\overline{G_{C}}=\frac{\bar{Y}^{\vartheta} G C}{\bar{b}^{\gamma} G C}$. The public capital accumulation equation (18) provides public capital $\overline{K_{G}}=\frac{\overline{G^{I}}}{\delta^{g}}=\frac{\bar{Y}^{\vartheta} G I}{\delta^{g} \bar{b}^{\gamma G I}}$, from which fiscal debt can be expressed in terms of output and public capital $\bar{b}=\left(\frac{\bar{Y}^{\vartheta} G I}{\overline{\bar{K}_{G}} \delta^{g}}\right)^{1 / \gamma_{G I}}$. The steady state lump-sum taxes can be found by plugging the previous three equations for fiscal debt, public consumption, and public investment into the tax equation (21) $\bar{T}=\frac{\frac{\vartheta_{G I} \varphi_{b}-\vartheta_{G I} \varphi_{C} \gamma_{G C}+\vartheta_{G C} \varphi_{C} \gamma_{G I}}{\gamma_{G I}}}{\left(\overline{K_{G}} \delta^{g}\right) \frac{\varphi_{b}-\gamma_{G C} \varphi_{C}-\gamma_{G I} \varphi_{I}}{\gamma_{G I}}}$. Therefore, the government budget constraint (17) can be written in terms of output and public capital:

$$
\begin{aligned}
\left(\frac{\bar{Y}^{\vartheta_{G I}}}{\overline{K_{G}} \delta^{g}}\right)^{1 / \gamma_{G I}}+\frac{\bar{Y}^{\frac{\vartheta_{G I} \varphi_{b}-\vartheta_{G I} \varphi_{C} \gamma_{G C}+\vartheta_{G C} \varphi_{C} \gamma_{G I}}{\gamma_{G I}}}}{\left(\overline{K_{G}} \delta^{g}\right)^{\frac{\varphi_{b}-\gamma_{G C} \varphi_{C}-\gamma_{G I} \varphi_{I}}{\gamma_{G I}}}}= & \bar{R}\left(\frac{\bar{Y}}{\overline{K_{G}} \delta^{g}}\right)^{1 / \gamma_{G I}}+ \\
& +\overline{K_{G}} \delta^{g}+\bar{Y}^{\vartheta_{G C}-\frac{\vartheta_{G I} \gamma_{G C}}{\gamma_{G I}}}\left(\overline{K_{G}} \delta^{g}\right)^{\frac{\gamma_{G C}}{\gamma_{G I}}}
\end{aligned}
$$

The first-order condition with respect to capital (7) given that $\bar{Q}=1$ yields the following steady state rental cost of capital:

$$
\bar{R}^{k}=\frac{1}{\beta}-(1-\delta)-\frac{\bar{\xi} \Omega}{\beta}
$$

The problem of a firm is to equate the real marginal cost (15) with the inverse of price frictionless mark-up $\mu^{p}$ at steady state (Gali, 2008); thus, wage can be found as:

$$
\bar{W}=(1-\alpha)\left(\frac{{\overline{K_{G}}}^{\psi} \alpha^{\alpha}}{\left(\bar{R}^{k}\right)^{\alpha} \mu^{p}}\right)^{\frac{1}{1-\alpha}}
$$

The labor supply condition (10) gives $\bar{N}=\bar{W}^{\frac{1}{\phi-1}}$. Therefore, the production function (14) suggests that output can be expressed in terms of private capital and public capital:

$$
\bar{Y}=\bar{K}^{\alpha} \bar{K}_{G} \frac{\psi \phi}{\phi-1}\left(\frac{\alpha^{\alpha}(1-\alpha)^{1-\alpha}}{\left(\bar{R}^{k}\right)^{\alpha} \mu^{p}}\right)^{\frac{1}{\phi-1}}
$$

This means that the government budget constraint (30) can be rewritten in terms of the both types of capital constituting the first equation in the system. The second equation in that system comes from the market clearing condition shown gradually below.

The law of motion for physical capital (3) suggests $\bar{I}=\delta \bar{K}$.

The steady state taxes of rule-of-thumb households are equal to $\overline{T^{N}}=\frac{\bar{T}-(1-\mu) \overline{T^{S}}}{\mu}$ 
given that $T_{t}=\mu T_{t}^{N}+(1-\mu) T_{t}^{S}$, while the taxes of optimizers can be found from their budget constraint (2) given that both types of households have equal consumption at steady state.

$$
\overline{T^{S}}=\mu\left[\left(\bar{R}^{k}-\delta\right) \bar{K}+\bar{b}(\bar{R}-1)+\overline{b^{*}}\left(1-\overline{R^{*}}\right)+\frac{\mu^{p}-1}{\mu^{p}} \bar{Y}\right]+\bar{T}
$$

The budget constraint of rule-of-thumb households (12) provides their consumption $\overline{C^{N}}=\overline{W N}-\overline{T^{N}}$, which is assumed to be equal to the consumption of optimizers, thus to aggregate consumption, given that it sums up the consumption of both households: $\bar{C}=\mu \overline{C^{N}}+(1-\mu) \overline{C^{S}}$.

The steady state exchange rate can be found from the Taylor rule (22):

$$
\bar{e}=\left[\frac{\bar{R}}{\bar{Y}^{\phi_{y}}}\right]^{1 / \phi_{e}}
$$

According to the intervention rule (23), the foreign exchange intervention is as follows:

$$
\overline{\operatorname{Int}}=\bar{e}^{\alpha_{1}}
$$

The collateral constraint (4) allows expressing the foreign debt in terms of private capital:

$$
\overline{b^{*}}=\frac{\Omega \bar{K}}{\bar{R}^{*}}
$$

The balance of payments equation (26) provides the steady state net exports:

$$
\overline{N X}=(1-\mu)\left(\Omega \bar{K}-\frac{\Omega \bar{K}}{\bar{R}^{*}}\right)+\left[\frac{\bar{R}}{\bar{Y}^{\phi_{y}}}\right]^{\alpha_{1} / \phi_{e}}
$$

Therefore, the market clearing condition (25) can be utilized as a second equation in the system to find the private and public capital:

$\bar{Y}=\delta \bar{K}+\overline{K_{G}} \delta^{g}+\bar{Y}^{\vartheta_{G C}-\frac{\vartheta_{G I} \gamma_{G C}}{\gamma_{G I}}}\left(\overline{K_{G}} \delta^{g}\right)^{\frac{\gamma_{G C}}{\gamma_{G I}}}+\bar{C}+(1-\mu)\left(\Omega \bar{K}-\frac{\Omega \bar{K}}{\bar{R}^{*}}\right)+\left[\frac{\bar{R}}{\bar{Y}^{\phi_{y}}}\right]^{\frac{a_{1}}{\phi_{e}}}$,

where output is plugged from the equation (32).

Since private and public capital can be found in the system of two equations (30 and 35), we can extract all the other steady state variables from our earlier substitutions: output, investment, consumption, hours worked, fiscal debt, public investment, public consumption, lump-sum taxes, foreign debt, exchange rate, intervention, and net exports.

\subsection{The Phillips curve}

The Phillips curve for CPI inflation in a small open economy has been derived according to Gali (2008). The log-linearized optimal price setting condition (16) 
can deliver the standard equation for domestic inflation $\pi_{t}^{h}$ :

$$
\pi_{t}^{h}=\beta E_{t} \pi_{t+1}^{h}+\lambda \widehat{m c_{t}}
$$

where $\widehat{m c_{t}}$ is the log deviation of the economy's average real marginal cost from its steady state and $\lambda=\frac{(1-\beta \theta)(1-\theta)}{\theta}$.

The CPI inflation includes the domestic inflation $\pi_{t}^{h}$ and the terms of trade, which can be alternatively represented by the real exchange rate $R E R_{t}$ :

$$
\pi_{t}=\pi_{t}^{h}+\frac{1-\gamma}{\gamma} \triangle \ln R E R_{t}
$$

where $\triangle \ln R E R_{t}=\triangle \ln e_{t}+\pi_{t}^{*}-\pi_{t}$.

The Phillips curve is as follows taking into account the previous CPI inflation equation (36):

$$
\pi_{t}=\beta E_{t} \pi_{t+1}+\lambda \widehat{m c}_{t}-\beta \frac{1-\gamma}{\gamma} \Delta \ln R E R_{t+1}+\frac{1-\gamma}{\gamma} \Delta \ln R E R_{t}
$$

where $\widehat{m c}_{t}=\widehat{W}_{t}-\left(\widehat{Y}_{t}-\widehat{N}_{t}\right)+\frac{1-\gamma}{\gamma} \widehat{R E R_{t}}$.

The real exchange rate can be derived from the international risk sharing condition typically considered in a small open economy. For this model, I equate the first-order condition with respect to foreign debt (9) with the analogous counterpart relevant for the foreign world, assuming that foreign securities are internationally traded:

$$
\beta E_{t}\left\{\frac{U_{C_{t+1}^{S}}}{U_{C_{t}^{S}}} \frac{P_{t}}{P_{t+1}} \frac{e_{t+1}}{e_{t}}\right\}+\xi_{t}=\beta^{*} E_{t}\left\{\frac{U_{C_{t+1}^{* S}}}{U_{C_{t}^{* S}}} \frac{P_{t}^{*}}{P_{t+1}^{*}}\right\}+\xi_{t},
$$

which can be rewritten as follows given that the law of one price holds, $R E R_{t}=\frac{e_{t} P_{t}^{*}}{P_{t}}$

$$
E_{t}\left\{\frac{U_{C_{t+1}^{S}}}{U_{C_{t}^{S}}}\right\}=\frac{\beta^{*}}{\beta} E_{t}\left\{\frac{U_{C_{t+1}^{* S}}}{U_{C_{t}^{* S}}} \frac{R E R_{t}}{R E R_{t+1}}\right\}
$$

I assume that the domestic economy and the foreign world have identical household utilities and equal hours worked $N_{t}=N_{t}^{*}$. Therefore, the previous equation (37) can be represented as $R E R_{t}=\frac{\beta}{\beta^{*}}\left(\frac{C_{t}^{S}-\frac{N_{t}^{\phi}}{\phi}}{C_{t}^{* S}-\frac{N_{t}^{\phi}}{\phi}}\right)^{\sigma}$, the log-linearization of which ends up to:

$$
\widehat{R E R_{t}}=\frac{\sigma \overline{C^{S}}}{\overline{C^{S}}-\frac{\bar{N}^{\phi}}{\phi}} \widehat{C_{t}^{S}}-\frac{\sigma \overline{C^{*}}}{\overline{C^{*}}-\frac{\bar{N}^{\phi}}{\phi}} \widehat{C_{t}^{*}}+\left(\frac{\sigma \bar{N}^{\phi}}{\overline{C^{*}}-\frac{\bar{N}^{\phi}}{\phi}}-\frac{\sigma \bar{N}^{\phi}}{\overline{C^{S}}-\frac{\bar{N}^{\phi}}{\phi}}\right) \widehat{N}_{t},
$$

where $\widehat{C_{t}^{*}}=\widehat{Y_{t}^{*}}$ and $\overline{C^{*}}=1$.

Given the aggregate consumption equation $C_{t}=\mu C_{t}^{N}+(1-\mu) C_{t}^{S}$ and the equal consumption of both households at steady state, the consumption of optimizer $\widehat{C_{t}^{S}}=\frac{\widehat{C_{t}}-\mu \widehat{C_{t}^{N}}}{1-\mu}$, while the consumption of rule-of-thumb household can be derived 
from its budget constraint $\widehat{C_{t}^{N}}=\frac{\bar{N}^{\phi} \phi}{\overline{C^{N}}} \widehat{N_{t}}-\frac{\overline{T^{N}}}{\overline{C^{N}}} \widehat{T_{t}^{N}}$. Following Gali, Lopez-Salido, and Valles (2007), I plug the lump-sum taxes rule (21) in $\widehat{T_{t}^{N}}$ and obtain the following equation for the consumption of optimizer:

$$
\widehat{C_{t}^{S}}=\frac{1}{1-\mu} \widehat{C}_{t}-\frac{\mu}{1-\mu}\left[\frac{\overline{N^{\phi}} \phi}{\overline{C^{N}}} \widehat{N}_{t}-\frac{\overline{T^{N}}}{\overline{C^{N}}}\left(\varphi_{b} \widehat{b}_{t-1}+\varphi_{I}\left(\frac{\widehat{K}_{G, t}-\left(1-\delta^{g}\right) \widehat{K}_{G, t-1}}{\delta^{g}}\right)+\varphi_{C} \widehat{G_{t}^{C}}\right)\right]
$$

Finally, combining the equations for consumption of optimizer $\widehat{C_{t}^{S}}$, real exchange rate $\widehat{R E R}_{t}$, and average real marginal cost $\widehat{m c}_{t}$, the Phillips curve of CPI inflation is as follows:

$$
\begin{aligned}
\pi_{t}= & \beta E_{t} \pi_{t+1}+\gamma \lambda\left(\left[\frac{1-\gamma}{\gamma}\left(\frac{\sigma \bar{N}^{\phi}}{1-\frac{\bar{N}^{\phi}}{\phi}}-\frac{\sigma \bar{N}^{\phi}}{\overline{C^{S}}-\frac{\bar{N}^{\phi}}{\phi}}-\frac{\sigma \mu \bar{N}^{\phi} \phi}{\left.\overline{\left(C^{S}\right.}-\frac{\bar{N}^{\phi}}{\phi}\right)(1-\mu)}\right)+\right.\right. \\
& +\phi] \widehat{N}_{t}+\frac{1-\gamma}{\gamma}\left[\frac { \sigma \overline { C ^ { S } } } { \overline { C ^ { S } } - \frac { \overline { N } ^ { \phi } } { \phi } } \left(\frac{1}{1-\mu} \widehat{C}_{t}+\frac{\mu \overline{T^{N}}}{(1-\mu) \overline{C^{N}}}\left(\varphi_{I}\left(\frac{\widehat{K}_{G, t}-\left(1-\delta^{g}\right) \widehat{K}_{G, t-1}}{\delta^{g}}\right)+\right.\right.\right. \\
& \left.\left.\left.\left.+\varphi_{b} \widehat{b}_{t-1}+\varphi_{C} \widehat{G_{t}^{C}}\right)\right)-\frac{\sigma}{1-\frac{\bar{N}^{\phi}}{\phi}} \widehat{Y}_{t}^{*}\right]-\widehat{Y}_{t}\right)-(1-\gamma) \beta E_{t} \pi_{t+1}^{*}+(1-\gamma) \pi_{t}^{*}- \\
& -\beta(1-\gamma) E_{t} \widehat{e}_{t+1}+(1-\gamma)(1+\beta) \widehat{e}_{t}-(1-\gamma) \widehat{e}_{t-1}
\end{aligned}
$$

\subsection{Log-linearized equations}

The final 10 log-linearized equations of the model are listed below.

The Phillips curve of CPI inflation (38) is derived in Appendix 6.3.

The log-linearization of net exports equation (26) has resulted in the following:

$$
\begin{aligned}
& \widehat{N X}_{t}=\frac{(1-\mu) \bar{R}^{*} \bar{b}^{*}}{\overline{N X}} \widehat{R}_{t-1}^{*}+\frac{(1-\mu) \bar{R}^{*} \bar{b}^{*}}{\overline{N X}} \Delta \widehat{e}_{t}-\frac{(1-\mu) \bar{b}^{*}}{\overline{N X}} \widehat{b}_{t}^{*}+ \\
& +\frac{(1-\mu) \bar{R}^{*} \bar{b}^{*}}{\overline{N X}} \widehat{b}_{t-1}^{*}-\frac{(1-\mu) \bar{R}^{*} \bar{b}^{*}}{\overline{N X}} \pi_{t}+\frac{\overline{\operatorname{Int}}}{\overline{N X}} \widehat{\operatorname{Int}}_{t},
\end{aligned}
$$

where $\frac{\bar{b}^{*}}{\overline{N X}}$ can be substituted with the ratio of two parameters $\frac{b_{y}^{*}}{n x_{y}}$, external debtto-GDP ratio and net exports-to-GDP ratio.

The collateral constraint (4) is log-linearized below:

$$
\begin{aligned}
\widehat{b}_{t}^{*}= & \widehat{K}_{t}+E_{t} \pi_{t+1}-\widehat{R}_{t}^{*}+\widehat{e}_{t}-E_{t} \widehat{e}_{t+1}+\frac{1}{(1-\widetilde{\gamma}) z}\left[\widehat{Y}_{t+1}-c_{y} \widehat{C}_{t+1}-g_{y}^{C} \widehat{G_{t+1}^{C}}-(40)\right. \\
& \left.-n x_{y} \widehat{N X}_{t+1}+\frac{g_{y}^{I}\left(1-\delta^{g}\right)}{\delta^{g}} \widehat{K}_{G, t}-\frac{g_{y}^{I}}{\delta^{g}} \widehat{K}_{G, t+1}-(1-\widetilde{\gamma}) \widehat{K}_{t}\right],
\end{aligned}
$$

where $(1-\widetilde{\gamma})=1-c_{y}-g_{y}^{C}-g_{y}^{I}-n x_{y}$ and the last term in squared brackets is for $\widehat{Q_{t+1}}=\frac{\widehat{I_{t+1}^{S}}-\widehat{K_{t}}}{z}$. 
The law of motion for physical capital (3) is as follows:

$$
\begin{aligned}
\widehat{K}_{t}= & (1-\delta) \widehat{K}_{t-1}+\frac{\delta}{1-\widetilde{\gamma}}\left[\widehat{Y}_{t}-c_{y} \widehat{C}_{t}-g_{y}^{C} \widehat{G}_{t}^{C}-n x_{y} \widehat{N X}_{t}+\right. \\
& \left.+\frac{g_{y}^{I}\left(1-\delta^{g}\right)}{\delta^{g}} \widehat{K}_{G, t-1}-\frac{g_{y}^{I}}{\delta^{g}} \widehat{K}_{G, t}\right]
\end{aligned}
$$

The combination of public capital (18) and public investment (19) equation is below:

$$
\begin{aligned}
\widehat{K}_{G, t}= & \left(\rho_{G I}+1-\delta^{g}\right) \widehat{K}_{G, t-1}-\rho_{G I}\left(1-\delta^{g}\right) \widehat{K}_{G, t-2}+ \\
& +\left(1-\rho_{G I}\right) \delta^{g}\left(\vartheta_{G I} \widehat{Y}_{t}-\gamma_{G I} \widehat{b}_{t-1}\right)+\delta^{g} \epsilon_{t}^{G I}
\end{aligned}
$$

The UIP condition (11) after some tedious algebra corresponds to:

$$
E_{t} \widehat{e}_{t+1}=\widehat{R}_{t}+\widehat{e}_{t}-\frac{\beta^{*}}{\bar{\beta}} \widehat{R}_{t}^{*}-\frac{\beta^{*}-\beta}{\beta} \widehat{\xi}_{t}
$$

where $\widehat{\xi}_{t}$ is an UIP shock.

The production function (14) implies:

$$
\widehat{Y}_{t}=\alpha \widehat{K}_{t-1}+(1-\alpha) \widehat{N}_{t}+\psi \widehat{K}_{G, t-1}+\widehat{a}_{t}, \quad \widehat{a}_{t}=\rho_{a} \widehat{a}_{t-1}+\epsilon_{t}^{a}
$$

The combination of log-linearized first-order conditions for capital (7) and investment (6) given that $\widehat{R_{t}^{k}}=\phi N_{t}-\widehat{K_{t-1}}$ delivers the following:

$$
\begin{aligned}
\frac{1}{(1-\widetilde{\gamma})} \widehat{Y}_{t}= & \frac{g_{y}^{C}}{(1-\widetilde{\gamma})} \widehat{G_{t}^{C}}+\frac{n x_{y}}{(1-\widetilde{\gamma})} \widehat{N X_{t}}+\frac{c_{y}}{(1-\widetilde{\gamma})} \widehat{C}_{t}-\frac{[\beta(1-\delta)+\Omega \bar{\xi}] g_{y}^{I}}{(1-\widetilde{\gamma}) \delta^{g}} \widehat{K}_{G, 4}(45) \\
& +\left[\frac{g_{y}^{I}+[\beta(1-\delta)+\Omega \bar{\xi}] g_{y}^{I}\left(1-\delta^{g}\right)}{(1-\widetilde{\gamma}) \delta^{g}}\right] \widehat{K}_{G, t}-\frac{g_{y}^{I}\left(1-\delta^{g}\right)}{(1-\widetilde{\gamma}) \delta^{g}} \widehat{K}_{G, t-1}+ \\
& +\widehat{K}_{t-1}+\frac{\beta(1-\delta)+\Omega \bar{\xi}}{(1-\widetilde{\gamma})}\left(\widehat{Y}_{t+1}-c_{y} \widehat{C}_{t+1}-g_{y}^{C} \widehat{G_{t+1}^{C}}-n x_{y} \widehat{N X}_{t+1}\right)- \\
& -z\left(\widehat{R}_{t}-E_{t} \pi_{t+1}\right)-\left[\beta(1-\delta)+\Omega \bar{\xi}+z\left(1-\beta(1-\delta)-\Omega \bar{\xi}^{\prime}\right)\right] \widehat{K}_{t}+ \\
& +z(1-\beta(1-\delta)-\Omega \bar{\xi}) \phi E_{t} \widehat{N}_{t+1}+z \Omega \bar{\xi}\left(E_{t} \pi_{t+1}+\widehat{e}_{t}-E_{t} \widehat{e}_{t+1}+\widehat{\xi}_{t}\right)
\end{aligned}
$$

The government budget constraint (17) jointly with the lump-sum taxes equation (21) can be represented as:

$$
\widehat{b}_{t}=\Psi_{b} \widehat{b}_{t-1}+\Psi_{i} \widehat{R}_{t-1}+\Psi_{k g}\left(\frac{\widehat{K}_{G, t}-\left(1-\delta^{g}\right) \widehat{K}_{G, t-1}}{\delta^{g}}\right)+\Psi_{g c} \widehat{G_{t}^{C}},
$$

where its coefficients are below in details.

$$
\Psi_{b}=\frac{\overline{b R}-\bar{T} \varphi_{b}}{\overline{b R}+\overline{G^{I}}+\overline{G^{C}}-\bar{T}}
$$




$$
\begin{aligned}
\Psi_{i} & =\frac{\overline{b R}}{\overline{b R}+\overline{G^{I}}+\overline{G^{C}}-\bar{T}} \\
\Psi_{k g} & =\frac{\overline{G^{I}}-\bar{T} \varphi_{I}}{\overline{b R}+\overline{G^{I}}+\overline{G^{C}}-\bar{T}} \\
\Psi_{g c} & =\frac{\overline{G^{C}}-\bar{T} \varphi_{C}}{\overline{b R}+\overline{G^{I}}+\overline{G^{C}}-\bar{T}}
\end{aligned}
$$

The aggregate consumption equation is derived according to Gali, Lopez-Salido, and Valles (2007) by combining the Euler equation (8), budget constraint of the rule-of-thumb households (12), lump-sum taxes equation (21), and the relationship $C_{t}=\mu C_{t}^{N}+(1-\mu) C_{t}^{S}$ :

$$
\begin{aligned}
\widehat{C}_{t}= & E_{t} \widehat{C}_{t+1}+\Theta_{n} \widehat{N}_{t}-\Theta_{n 1} E_{t} \widehat{N}_{t+1}-\Theta_{i}\left(\widehat{R}_{t}-E_{t} \pi_{t+1}\right)+\Theta_{b} \widehat{b}_{t}- \\
& -\bar{C}^{-1} \mu \overline{T^{N}} \varphi_{b} \widehat{b}_{t-1}+\Theta_{y} E_{t} \widehat{Y}_{t+1}+\Theta_{k g} \widehat{K}_{G, t}-\Theta_{k g 1} \widehat{K}_{G, t-1}+\Theta_{g c} \widehat{G}_{t}^{C},
\end{aligned}
$$

where its coefficients are shown below.

$$
\begin{gathered}
\Theta_{n}=\mu \bar{N}^{\phi} \phi \bar{C}^{-1}+\bar{C}^{-1}(1-\mu) \bar{N}^{\phi} \\
\Theta_{n 1}=\bar{C}^{-1}\left[(1-\mu) \bar{N}^{\phi}+\mu \phi \bar{N}^{\phi}\right] \\
\Theta_{i}=(\sigma \bar{C})^{-1}(1-\mu)\left(\bar{C}-\phi^{-1} \bar{N}^{\phi}\right) \\
\Theta_{b}=\bar{C}^{-1} \mu \overline{T^{N}}\left[\varphi_{b}-\varphi_{I} \gamma_{G I}\left(1-\rho_{G I}\right)-\varphi_{C} \gamma_{G C}\left(1-\rho_{G C}\right)\right] \\
\Theta_{y}=\bar{C}^{-1} \mu \overline{T^{N}}\left[\varphi_{I} \vartheta_{G I}\left(1-\rho_{G I}\right)+\varphi_{C} \vartheta_{G C}\left(1-\rho_{G C}\right)\right] \\
\Theta_{k g}=\left(\bar{C} \delta^{g}\right)^{-1} \mu \overline{T^{N}} \varphi_{I}\left(\rho_{G I}-1\right) \\
\Theta_{k g 1}=\left(\bar{C} \delta^{g}\right)^{-1} \mu \overline{T^{N}}\left(1-\delta^{g}\right) \varphi_{I}\left(\rho_{G I}-1\right) \\
\Theta_{g c}=\bar{C}^{-1} \mu \overline{T^{N}} \varphi_{C}\left(\rho_{G C}-1\right)
\end{gathered}
$$




\subsection{Impulse response functions under $\mu=0.75$}

Figure 1. Public investment shock
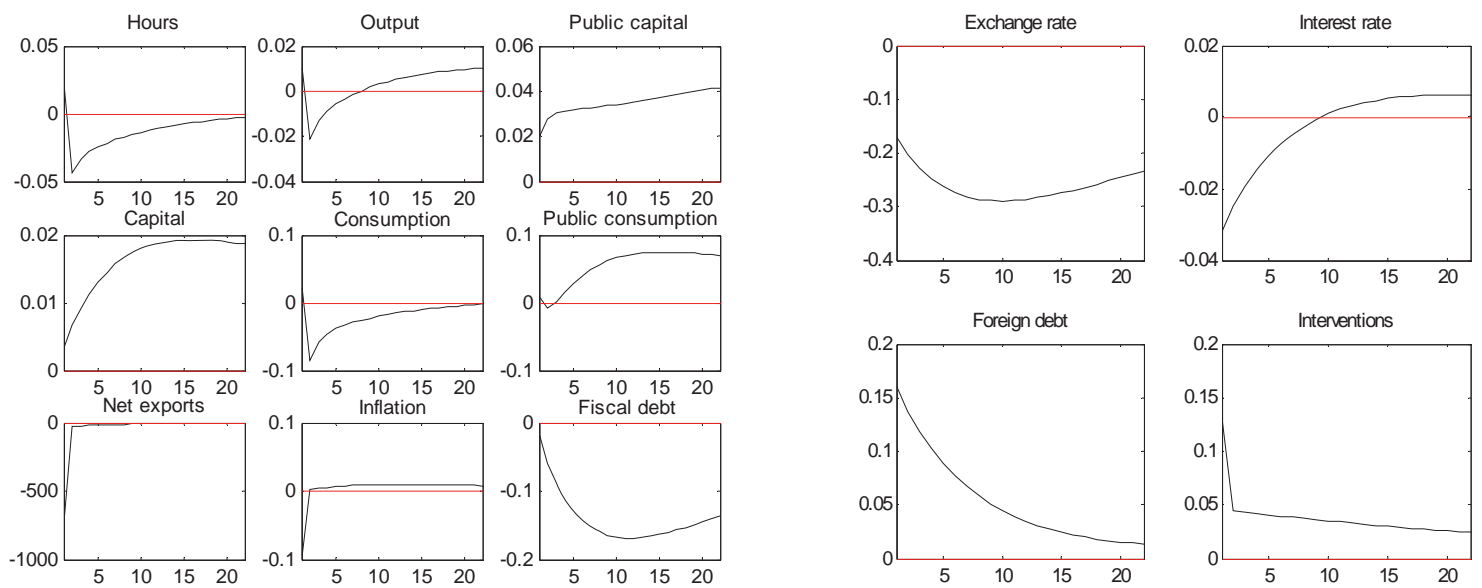

Figure 2. Public consumption shock
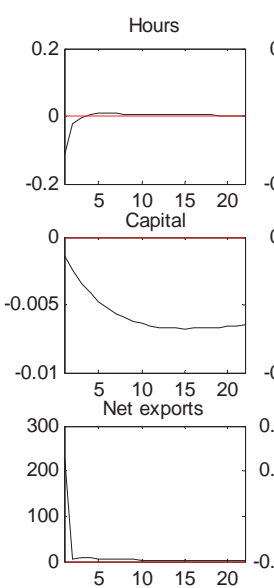
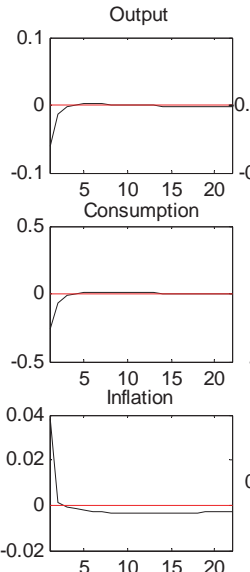
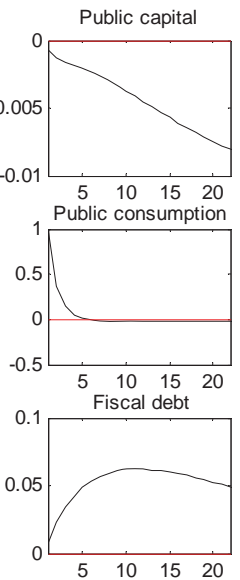
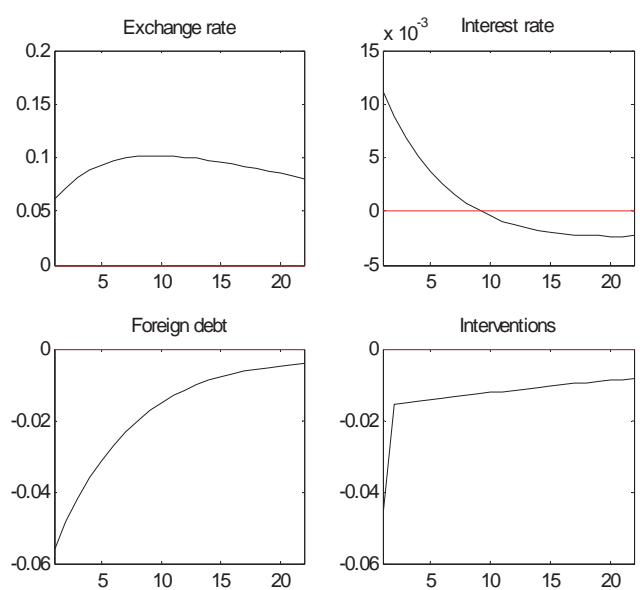


\section{Working Paper Series}

ISSN 1211-3298

Registration No. (Ministry of Culture): E 19443

Individual researchers, as well as the on-line and printed versions of the CERGE-EI Working Papers (including their dissemination) were supported from institutional support RVO 67985998 from Economics Institute of the ASCR, v. v. i.

Specific research support and/or other grants the researchers/publications benefited from are acknowledged at the beginning of the Paper.

(c) Aliya Algozhina, 2012

All rights reserved. No part of this publication may be reproduced, stored in a retrieval system or transmitted in any form or by any means, electronic, mechanical or photocopying, recording, or otherwise without the prior permission of the publisher.

Published by

Charles University in Prague, Center for Economic Research and Graduate Education (CERGE) and

Economics Institute ASCR, v. v. i. (EI)

CERGE-EI, Politických vězňů 7, 11121 Prague 1, tel.: +420 224005 153, Czech Republic.

Printed by CERGE-EI, Prague

Subscription: CERGE-EI homepage: http://www.cerge-ei.cz

Phone: + 420224005153

Email: office@cerge-ei.cz

Web: http://www.cerge-ei.cz

Editor: Michal Kejak

The paper is available online at http://www.cerge-ei.cz/publications/working_papers/.

ISBN 978-80-7343-280-5 (Univerzita Karlova. Centrum pro ekonomický výzkum a doktorské studium)

ISBN 978-80-7344-272-9 (Národohospodářský ústav AV ČR, v. v. i.) 
CERGE-EI

P.O.BOX 882

Politických vězňů 7

11121 Praha 1

Czech Republic http://www.cerge-ei.cz 